\title{
Pembuatan Jamban Ramah Lingkungan Sebagai Upaya Mengurangi Perilaku BABS Di Desa Cotkuta Kabupaten Nagan Raya
}

\author{
Meylis Safriani ${ }^{1}$, Enda Silvia Putri ${ }^{2}$, M. Arrie Rafshanjani ${ }^{3}$ \\ ${ }^{1,3}$ Program Studi Teknik Sipil Universitas Teuku Umar \\ ${ }^{2}$ Program Studi Kesehatan Masyarakat Universitas Teuku Umar \\ Email corresponding author: meylissafriani@utu.ac.id
}

\begin{abstract}
ABSTRAK
Salah satu desa yang terdapat di Kecamatan Suka Makmue, Kabupaten Nagan Raya adalah Desa Cotkuta. Desa ini masih tergolong desa yang sanitasinya rawan. Hal ini berdasarkan dari survei awal yaitu masih terdapat beberapa perumahan warga yang belum memiliki sarana sanitasi yang baik. Sebagian masyarakat di desa tersebut masih terbiasa melakukan buang air besar di berbagai tempat seperti saluran drainase, alue (anak sungai), saluran irigasi, dan bahkan di halaman kosong di belakang rumah mereka. Beberapa penyebab masyarakat belum memiliki jamban diantaranya adalah faktor ekonomi dan dikarenakan perilaku yang sudah menjadi kebiasaan. Pada pengabdian ini diperkenalkan cara membangun jamban yang murah dan ramah lingkungan dengan harga yang lebih efisien dibandingkan dengan jamban konvensional. Selain itu juga, masyarakat diberikan kegiatan sosialisasi mengenai manfaat dan pentingnya jamban serta bahaya Buang Air Besar Sembarangan (BABS). Pemberian materi kepada tim mitra dilakukan melalui kegiatan sosialisasi oleh tim pengabdian dari Universitas Teuku Umar Meulaboh. Pelaksanaan kegiatan pengabdian tentang pembuatan jamban ramah lingkungan telah dilakukan di Desa Cotkuta. Jamban ramah lingkungan dibuat dari material yang banyak terdapat di desa Cotkuta seperti bambu dan rumbia. Bambu dipergunakan sebagai dinding jamban, sedangkan rumbia dibuat menjadi atap jamban. Respon dari mitra sangat positif dan antusias, yang mana mereka sudah memahami cara membuat jamban secara mandiri dengan dana yang terjangkau. Mitra juga mau menerima inovasi yang diberikan serta memiliki minat yang tinggi dan bersedia untuk menerapkan inovasi yang telah diberikan.
\end{abstract}

Kata Kunci: BABS, Jamban, Sanitasi, Ramah Lingkungan, Efisien

\section{PENDAHULUAN}

Limbah yang terdapat di suatu area baik di perumahan, pemukiman, maupun perkamppungan akan bertambah seiring dengan pertambahan jumlah penduduk. Pada saat, limbah rumah tangga dibuang secara secara sembarangan dan bukan pada tempatnya maka akan menyebabkan kontaminasi terhadap lingkungan seperti kualitas air tanah. Air sumur dapat terkontaminasi akibat kondisi sistem pembuangan limbah yang dilakukan secara sembarangan. Masyarakat yang mengkonsumsi atau menggunakan air sumur tersebut dapat mengalami sakit perut, diare, dan gatal-gatal. Hal ini disebabkan oleh jumlah bakteri E. coli yang tinggi pada air sumur tersebut. Bakteri E.coli inilah yang berasal dari limbah yang dibuang secara sembarangan. Salah satu cara agar masyarakat tidak membuang limbah sembarangan yaitu dengan pembuatan jamban atau WC (water closet).

Desa Cot Kuta merupakan salah satu desa yang terdapat di Kecamatan Suka Makmue, Kabupaten Nagan Raya. Desa Cotkuta merupakan salah satu desa yang terdapat di Kecamatan Suka Makmue yang penduduknya kedua terpadat setelah Desa Luengbaroe dibandingkan dengan desa lain dengan jumlah penduduk 930 orang (BPS, 2018). Desa Cotkuta memiliki empat dusun di antaranya Dusun Paya, Dusun Paya Ubong, Dusun Beringin, dan Dusun Alue Gucie. Desa ini masih tergolong desa yang sanitasinya rawan. Hal ini berdasarkan dari survei 
awal yaitu masih terdapat beberapa perumahan warga yang belum memiliki sarana sanitasi yang baik. Sebagian masyarakat di desa tersebut masih terbiasa melakukan buang air besar di berbagai tempat seperti saluran drainase, alue (anak sungai), saluran irigasi, dan bahkan di halaman kosong di belakang rumah mereka. Beberapa penyebab masyarakat belum memiliki jamban diantaranya adalah faktor ekonomi dan dikarenakan perilaku yang sudah menjadi kebiasaan. Berikut ditampilkan tempat yang sering dijadikan warga untuk melakukan buang air besar.
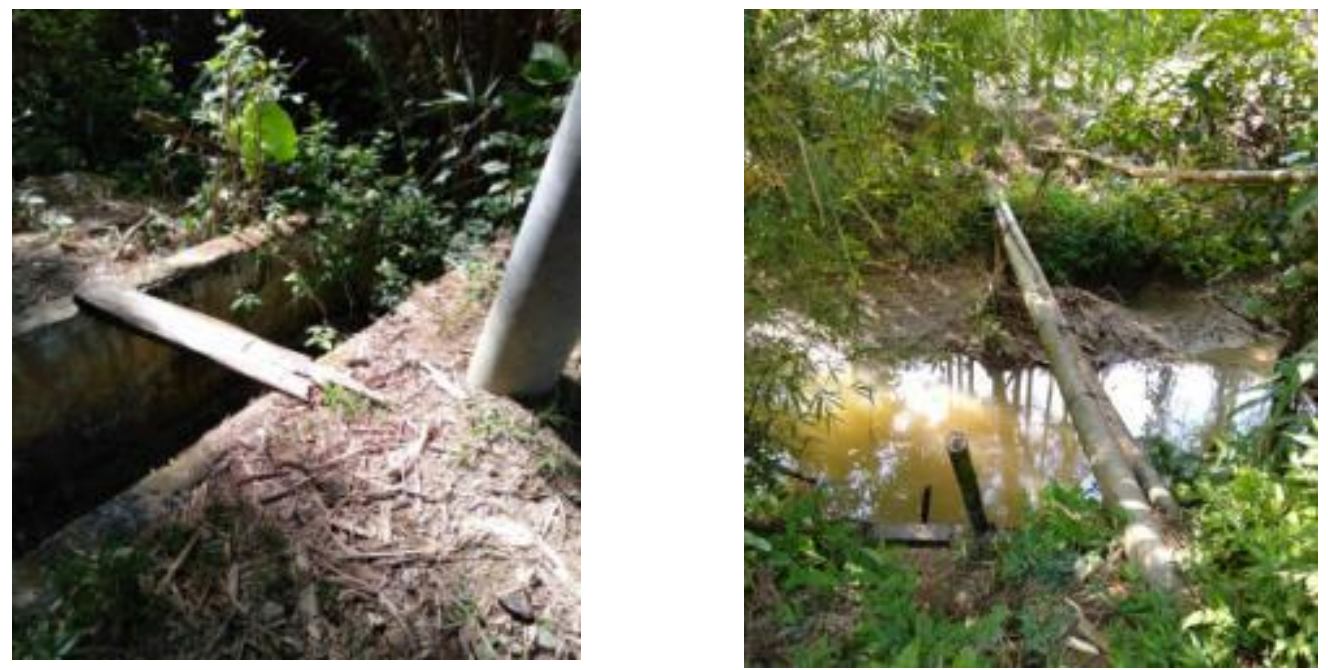

Gambar 1. Lokasi alue dan drainase yang sering dijadikan warga sebagai tempat BAB

Masyarakat di Desa Cotkuta terutama di Dusun Alue Guci pada umumnya belum memiliki WC (Water Closet) atau jamban. Penduduk di Dusun tersebut pada umumnya bekerja sebagai petani (85\%), pekebun (11\%), dan pedagang (4\%). Survei awal di Desa Cotkuta mengenai buangan limbah warga yakni selain masyarakat membuang limbah tidak pada tempatnya, terdapat juga masyarakat belum memiliki jamban. Hasil wawancara dengan warga di Dusun ini, penyebab utama masyarakat tidak mampu membangun jamban adalah keterbatasan dana atau tidak memiliki dana yang cukup untuk membangun jamban. Pada pengabdian ini akan diperkenalkan bagaimana cara membangun jamban ramah lingkungan secara mandiri dengan bahan dan material bangunan yang digunakan lebih sederhana, hemat biaya dan mudah ditemukan.

Berdasarkan permasalahan di atas, maka kegiatan pengabdian mengenai pengenalan jamban ramah lingkungan perlu dilakukan sebagai upaya untuk mengurangi perilaku kebiasaan BABS warga yang terjadi pada desa ini. Jamban merupakan salah satu fasilitas sanitasi dasar yang dibutuhkan dalam setiap rumah untuk mendukung kesehatan penghuninya sebagai fasilitas pembuangan kotoran manusia, yang terdiri atas tempat jongkok atau tempat duduk dengan leher angsa atau tanpa leher angsa yang dilengkapi dengan unit penampungan kotoran dan air untuk membersihkannya (Proverawati, 2012). Selain itu menurut Madjid (2009), jamban adalah suatu bangunan yang dipergunakan untuk membuang tinja atau kotoran manusia yang lazim disebut kakus. Menurut Kusnoputranto (2008), jamban adalah suatu bangunan yang digunakan untuk membuang dan mengumpulkan kotoran sehingga kotoran tersebut tersimpan dalam suatu tempat tertentu dan tidak menjadi penyebab suatu penyakit serta tidak mengotori permukaan.

Jamban sangat berguna bagi manusia dan merupakan bagian dari kehidupan manusia, karena jamban dapat mencegah berkembangbiaknya berbagai penyakit yang disebabkan oleh kotoran manusia yang tidak dikelola dengan baik. Sebaliknya jika pembuangan tinja tidak baik dan sembarangan dapat mengakibatkan kontaminasi pada air, tanah, atau menjadi sumber infeksi, dan akan mendatangkan bahaya bagi kesehatan, karena penyakit yang tergolong water 
borne disease seperti diare, kolera, dan kulit akan mudah berjangkit (Notoatmodjo, 2010).

Menurut Depkes RI (2009), jamban keluarga sehat adalah jamban yang memenuhi syarat-syarat sebagai berikut:

1. Sumber air minum tidak tercemar, lubang penampung memiliki jarak 10 hingga 15 meter dari sumber air minum

2. Tidak memiliki bau dan tinja tidak dapat dijamah oleh tikus maupun serangga

3. Cukup luas dan landai/miring ke arah lubang jongkok sehingga tidak mencemari tanah di sekitarnya

4. Saat dibersihkan mudah dilakukan dan penggunaannya aman

5. Memiliki dinding dan atap pelindung, dinding kedap air dan berwarna

6. Memiliki penerangan yang cukup

7. Lantai kedap air

8. Ventilasi cukup baik

9. Tersedia air dan alat pembersih

Pada kegiatan pengabdian ini diperkenalkan mengenai cara merakit bambu, memasang atap dengan rumbia, dan membuat cor an lantai jamban. Bambu yang telah dirakit dipasang sebagai dinding jamban. Bambu hasil rakitan ini mesti kokoh dan kuat sehingga tidak mudah goyah saat angin menerpa. Pada penggunaan jamban sehari-hari, bagian dinding bawah akan sering terkena air pada saat jamban digunakan sehingga perlu dilapisi dengan terpal agar dinding akan lebih tahan lama. Untuk mempertahankan bambu dari cuaca panas dan hujan, bambu dilapisi dengan minyak oli terlebih dahulu. Kelompok mitra bersama tim pengabdian dari UTU bersama-sama membangun jamban ini.

Masyarakat yang akan menjadi sasaran kegiatan pengabdian kepada masyarakat adalah warga masyarakat yang berprofesi sebagai tukang bangunan. Tim pengabdi terdiri Dosen Program Studi Teknik Sipil dan Dosen Program Studi Kesehatan Masyarakat Universitas Teuku Umar. Adapun tujuan pengabdian kepada masyarakat yakni untuk meningkatkan pengetahuan tentang manfaat dan pentingnya jamban serta bahaya BABS, memberikan keterampilan dan pemahaman kepada tim mitra mengenai cara membuat jamban ramah lingkungan yang biayanya sangat efisisen dibandingkan jamban konvensional.

\section{METODE KEGIATAN}

Metode yang digunakan adalah kegiatan sosialisasi dan pelatihan kepada masyarakat melalui:

1) Pemberian materi kepada tim mitra mengenai manfaat dan tujuan jamban, bahaya Buang Air Besar Sembarangan (BABS). Pada saat pemberian materi ini terdapat diskusi dan tanya jawab tentang penerapan jamban ramah lingkungan, dan perbandingan harga antara jamban ramah lingkungan dengan jamban konvensional. Tim mitra dinamakan kelompok Sehat yang terdiri dari 4 orang.

2) Pendampingan mengenai langkah-langkah membuat jamban ramah lingkungan. Pada kegiatan ini dijelaskan proses pembuatan jamban ramah lingkungan. Penggunaan material yang mandiri pada pembuatan jamban diharapkan dapat mengurangi biaya pengeluaran dalam pembuatan jamban sehingga masyarakat di Desa Cotkuta dapat lebih tertarik dalam membuat jamban ramah lingkungan secara mandiri. Jamban ini lebih hemat tiga kali dan efisien dibandingkan dengan Jamban konvensional. Jamban ramah lingkungan direncanakan untuk digunakan oleh 1 KK yang terdiri dari 5 sampai 6 anggota keluarga. Ukuran bangunan jamban direncanakan $2 \times 2$ meter.

3) Pelatihan pembuatan jamban ramah lingkungan dengan menggunakan metode praktek langsung. Pelatihan awal terlebih dahulu diberitahukan materi tentang materialmaterial yang diperlukan dan cara pelaksanaannya. Pada saat kegiatan pelatihan ditunjukkan gambar desain jamban ramah lingkungan dimana bahan-bahannya 
memang merupakan sumber daya lokal yang terdapat di Kabupaten Nagan Raya dan dan ditunjukan langkah-langkah cara membuat jamban ramah lingkungan tersebut. Material seperti bambu dan daun rumbia dicari terlebih dahulu sedangkan material seperti semen, pasir, batu dipersiapkan juga.

4) Pemantauan secara berkala, untuk tim Pelaksana dilakukan dengan site visited ke lokasi, dua minggu sekali. Untuk Mitra Kelompok Sejahtera dapat dilakukan setiap hari

Jamban ramah lingkungan adalah jamban yang dibuat oleh masyarakat itu sendiri tanpa memberi upah kepada tukang dengan memanfaatkan material potensi sumber daya alam yang ada di Desa Cotkuta. Pada Gambar berikut ditamppilkan potensi sumber daya alam yang terdapat di Desa Cotkuta dan dapat dimanfaatkan oleh warga untuk pembuatan atap dan dinding. Berikut ditampilkan ketersediaan daun rumbia yang digunakan untuk pembuatan atap jamban.
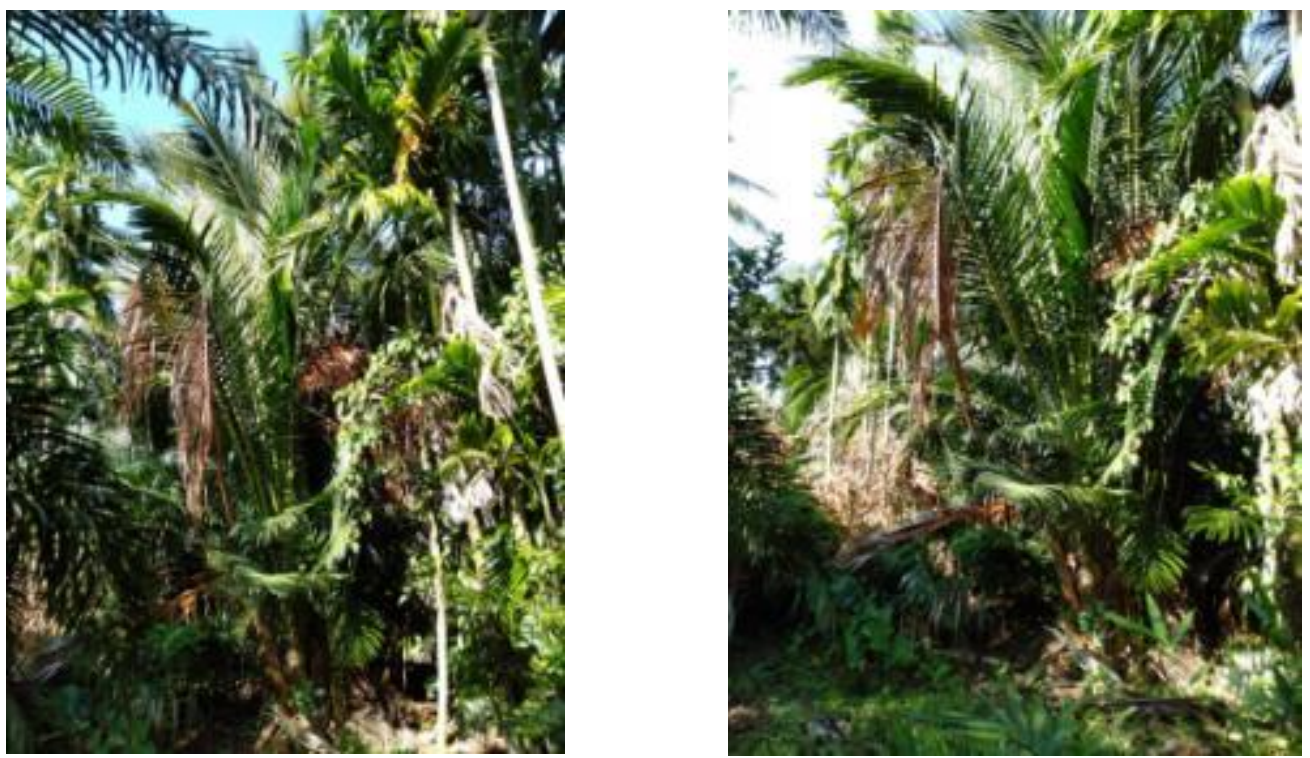

Gambar 2. Daun Rumbia potensi sumber daya alam yang terdapat di Desa Cotkuta dan dapat dimanfaatkan oleh warga untuk pembuatan atap jamban ramah lingkungan

Pada jamban ramah lingkungan, pembuatan bangunan ini sama halnya dengan pembuatan jamban pada umumnya. Namun, bahan material yang diganti dengan yang lebih murah seperti dinding bata diganti dengan material bambu. Atap seng diganti dengan atap daun rumbia, lantai jamban tidak memakai keramik tetapi lantai cor -an biasa. Penggunaan bahan material ini bertujuan agar biaya yang dikeluarkan lebih hemat. Selain itu., bahan-bahan material seperti bambu dan rumbia juga merupakan potensi sumber daaya lokal yang ada di daerah Nagan Raya. Selama ini penggunaan bambu hanya sebatas untuk pembuatan kandang hewan ternak dan ada juga sebagai media pembuatan kue tradisional.

Pelatihan mengenai pembuatan jamban ramah lingkungan ini menjadi modal dasar kelompok mitra untuk dapat mengembangkan pembangunan jamban di tempat lain. Kelebihan jamban ramah lingkungan ini adalah materialnya mudah didapatkan dan biaya yang lebih efisien sehingga masyarakat yang kekurangan dana dapat membuat jamban ini. Bentuk partisipasi mitra dalam pelaksanaan program ini dengan membangun jamban sederhana yang ramah lingkungan dan tangki septik sehat sesuai yang diarahkan oleh tim pengabdian UTU. Setelah pengenalan desain/gambaran bangunan dan material-material yang diperlukan, maka tim mitra langsung membuat bangunan di lokasi yang telah disepakati secara bersama. Tim pengabdian mengkoordinir dan mendampingi tim mitra dalam pembuatan jamban 
tersebut. Waktu pelatihan dan pembuatan bangunan ini direncanakan selama 2 bulan. Untuk penggunaan jamban oleh $1 \mathrm{KK}$ yang terdiri dari 5 sampai 6 anggota keluarga dengan ukuran bangunan jamban direncanakan $2 \times 2$ meter dan tinggi 1,8 $\mathrm{m}$. Gambaran desain jamban ramah lingkungan ditampilkan pada Gambar berikut.

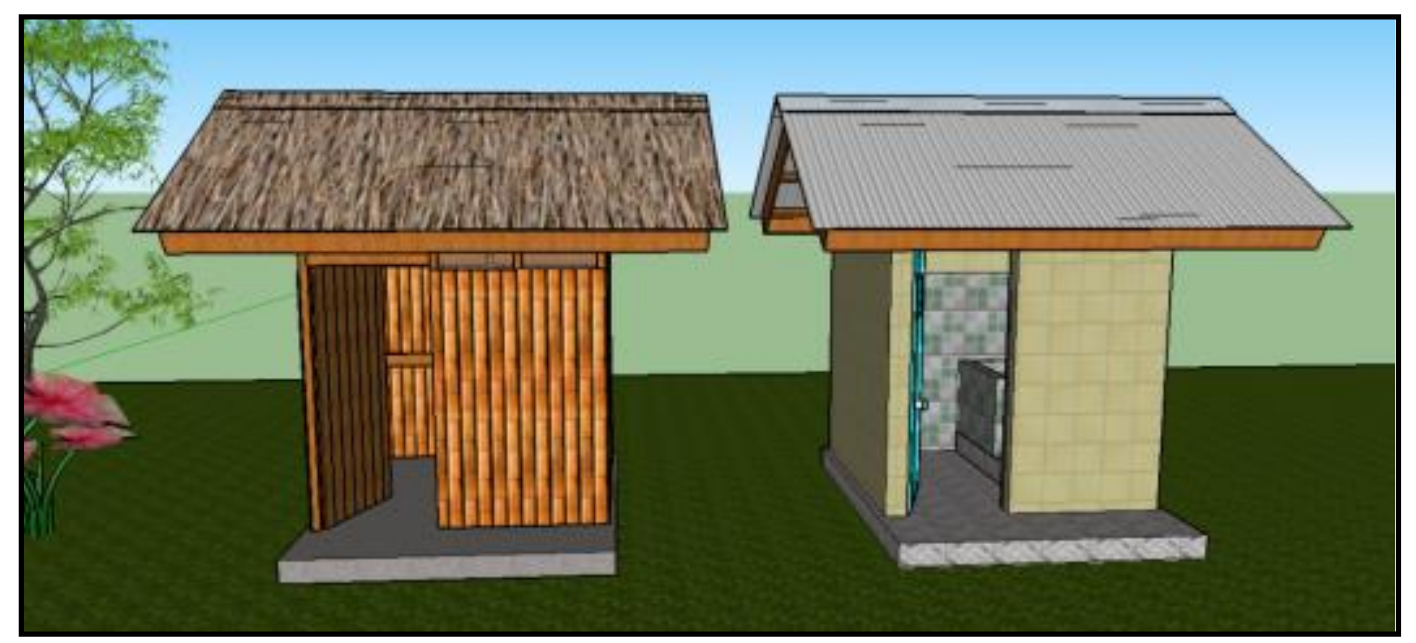

Gambar 3. Desain jamban ramah lingkungan dan jamban Konvensional

Penggunaan material yang ramah lingkungan pada pembuatan jamban diharapkan dapat mengurangi biaya pengeluaran dalam pembuatan jamban sehingga masyarakat di Desa Cotkutae dapat lebih tertarik dalam membuat jamban mandiri. WC ini lebih hemat tiga kali dan efisien dibandingkan dengan jamban konvensional.

\section{Rancangan Evaluasi}

Evaluasi dilakukan sejak awal kegiatan. Kriteria evaluasi adalah jumlah kehadiran dan persentase keaktifan anggota Mitra pada waktu penyampaian materi, diskusi, pendampingan, pelatihan dan penerapan langsung di lapangan dalam membuat tangki septik sehat.

Indikator pencapaian tujuan adalah:

1. Hadir ketika penyampaian materi dilaksanakan.

2. Aktif atau tidak aktifnya setiap anggota Mitra Kelompok Sejahtera ketika berdiskusi dan tanya jawab.

3. Hadir dan aktif pada saat pendampingan mengenai langkah-langkah membuat jamban ramah lingkungan

4. Hadir dan aktif pada saat pelatihan mengenai pembuatan jamban ramah lingkungan, praktek langsung di lapangan, ikut serta mempersiapkan bahan, alat, dan material.

5. Memantau kelanjutan kegiatan sampai dapat digunakan.

\section{HASIL DAN LUARAN YANG DICAPAI}

\section{Kegiatan Penyampaian Materi}

Kegiatan Penyampaian Materi atau kegiatan sosialisasi mengenai jamban ramah lingkungan telah dilakukan di Balai Desa Cot Kuta. Mitra kelompok yang diberi nama kelompok Sejahtera sangat tertarik dengan kegiatan ini, jamban ramah lingkungan berbeda dengan jamban konvensional yang ada di rumah warga selama ini. selain mudah dibuat, harganya juga efisien. Pada kegiatan sosialisasi ini dijabarkan tentang manfaat jamban, pentingnya jamban, dan bahaya perilaku Buang Air Besar secara Sembarangan (BABS). Ketertarikan mitra kelompok Sejahtera terhadap kegiatan sosialisasi dapat dilihat dari jumlah kehadiran yaitu 5 orang. 
Kegiatan ini turut dihadiri oleh Kepala Desa Cotkuta (Geuchik) yaitu Bapak Sulaiman TB, sekaligus membuka acara (Gambar 4).

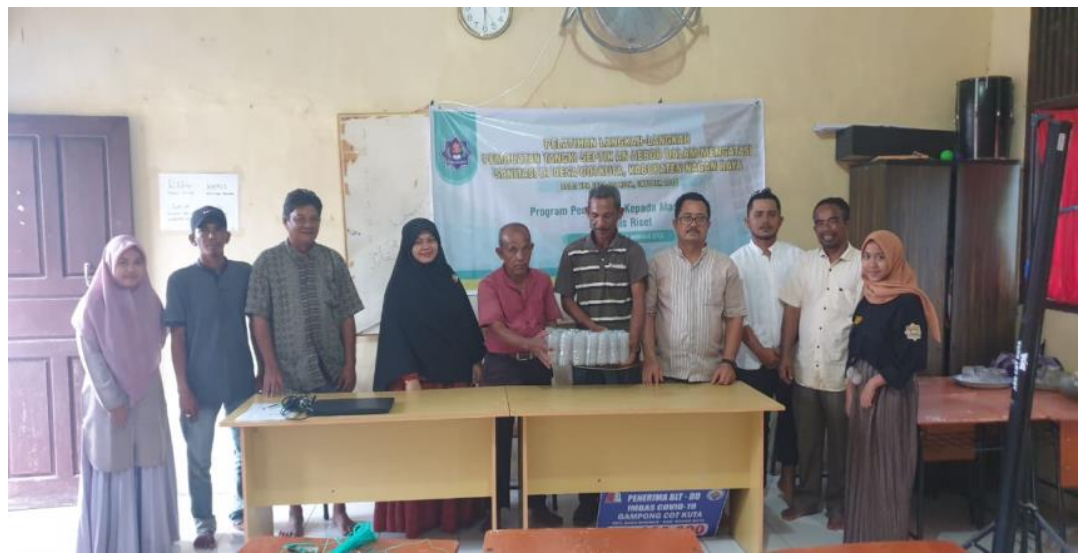

Gambar 4. Foto bersama mitra pada saat kegiatan sosialisasi

\section{Peninjauan Lokasi Pembuatan}

Penetapan lokasi pelaksanaan kegiatan dilakukan berdasarkan rumah warga yang dikatagorikan miskin/tidak mampu untuk membangun tangki septik. Hal ini berdasarkan hasil keputusan keuchik dan sekretaris desa.
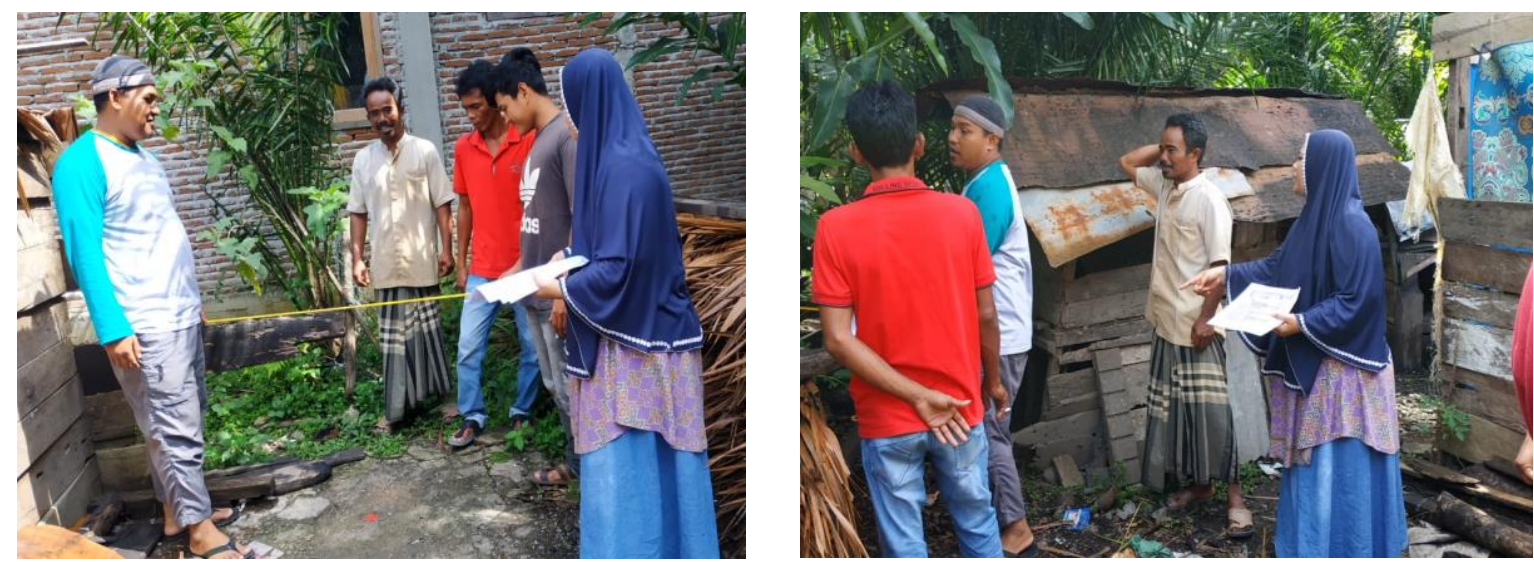

Gambar 5. Survei lokasi pembuatan jamban ramah lingkungan

\section{Penerapan Langsung}

Penerapan langsung/ praktek langsung oleh mitra ke lapangan untuk membangun jamban ramah lingkungan yang didampingi oleh tim pengabdian dari Universitas Teuku Umar Meulaboh. Tim mitra mencari dan mempersiapkan bahan material seperti semen, besi, papan, kayu, pasir, kerikil, paku, pipa PVC untuk limbah. Untuk pembuatan dinding dan atap, tim mitra mencarai bambu dan rumbia. Pada awalnya bambu dikeringkan terlebih dahulu dengan alami melalui pencahayaan matahari. Peralatan yang mendukung dan dibutuhkan dalam membuat jamban ramah lingkungan diantaranya gergaji, palu, kereta sorong, cangkul, dan sekop. Kegiatan awal yang dilakukan yaitu pembersihan lahan dari pohon dan semak belukar. Berikut proses pembuatan jamban ramah lingkungan dimulai dari persiapan material dan peralatan hingga pekerjaan selesai. 

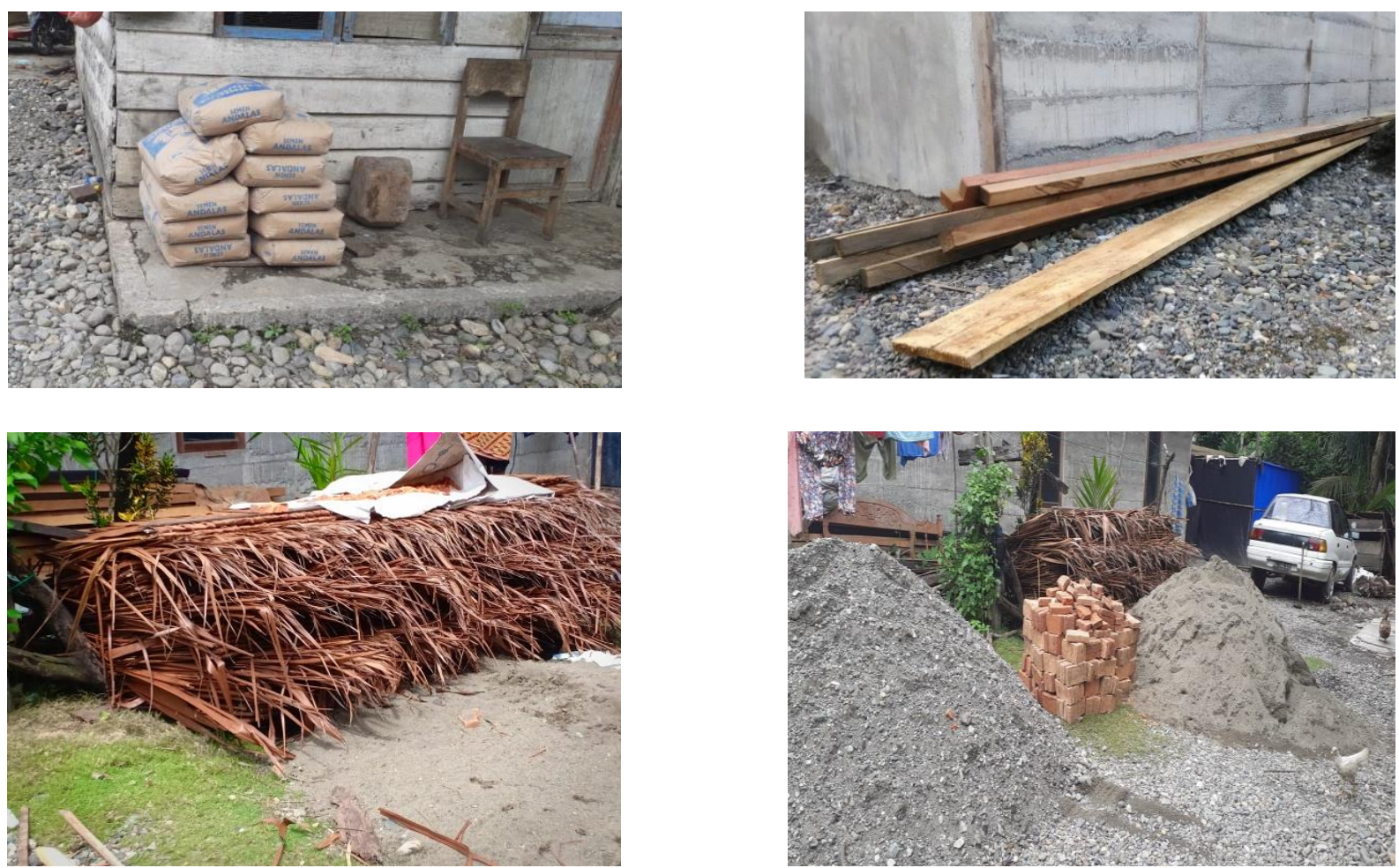

Gambar 6. Persiapan material untuk bahan pembuatan jamban ramah lingkungan
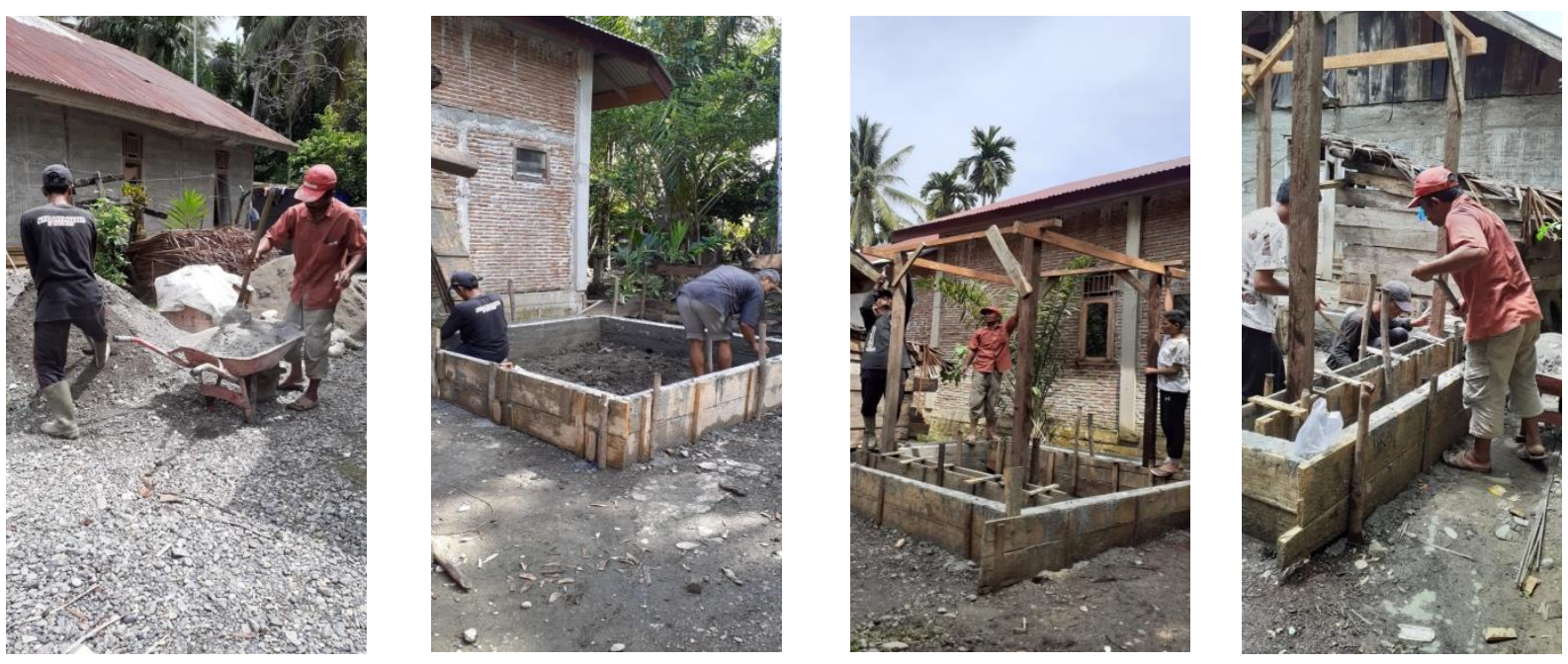

Gambar 7. Pembuatan bekisting dan rangka dinding jamban ramah lingkungan 

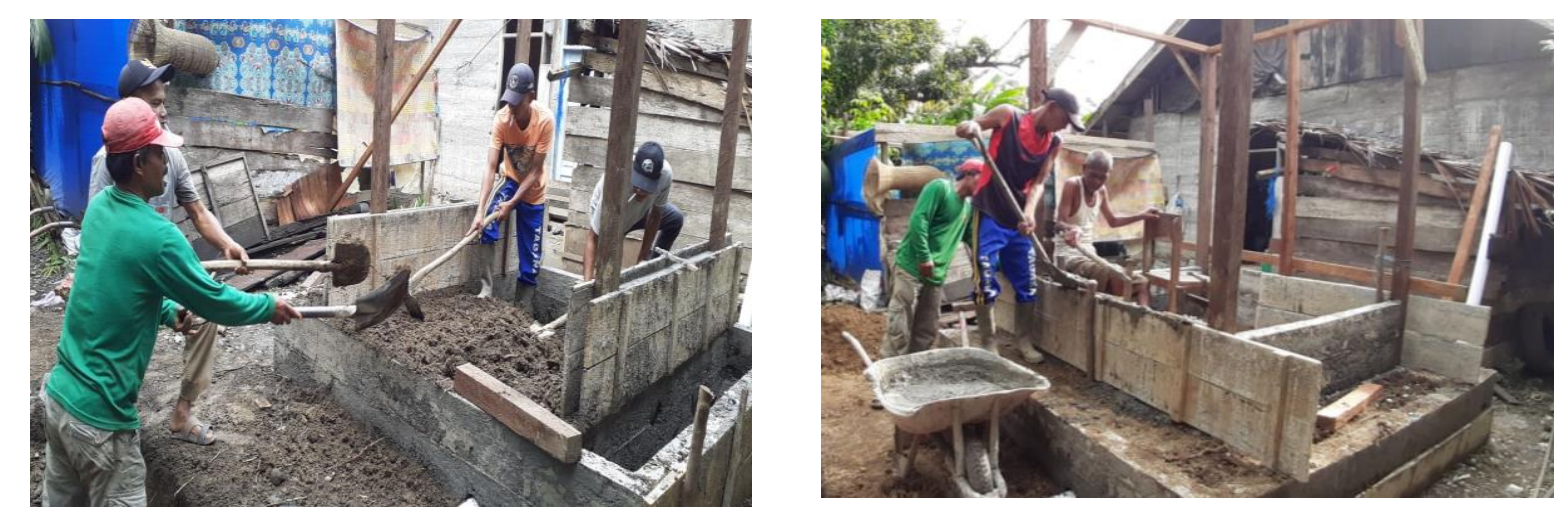

Gambar 8. Proses pembuatan pondasi jamban dan pengecoran dudukan dinding jamban
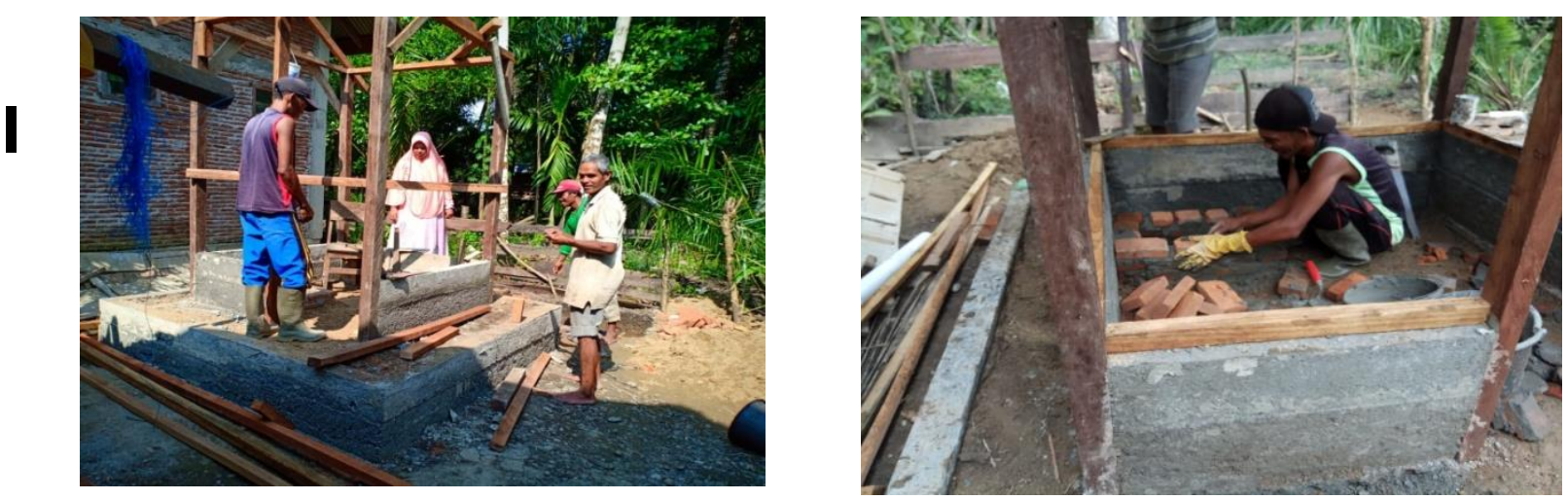

Gambar 9. Proses pembuatan rangka atap rumbia dan proses pembuatan dudukan kloset
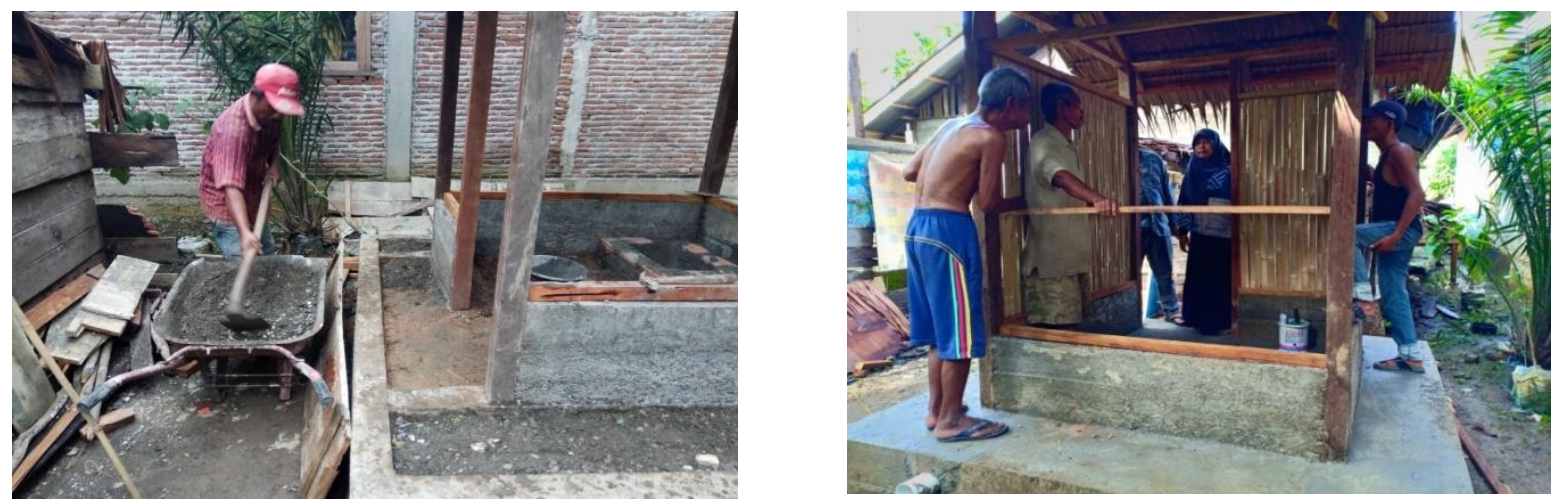

Gambar 10. Proses pembuatan lantai kerja dan pembuatan dinding jamban dari bambu
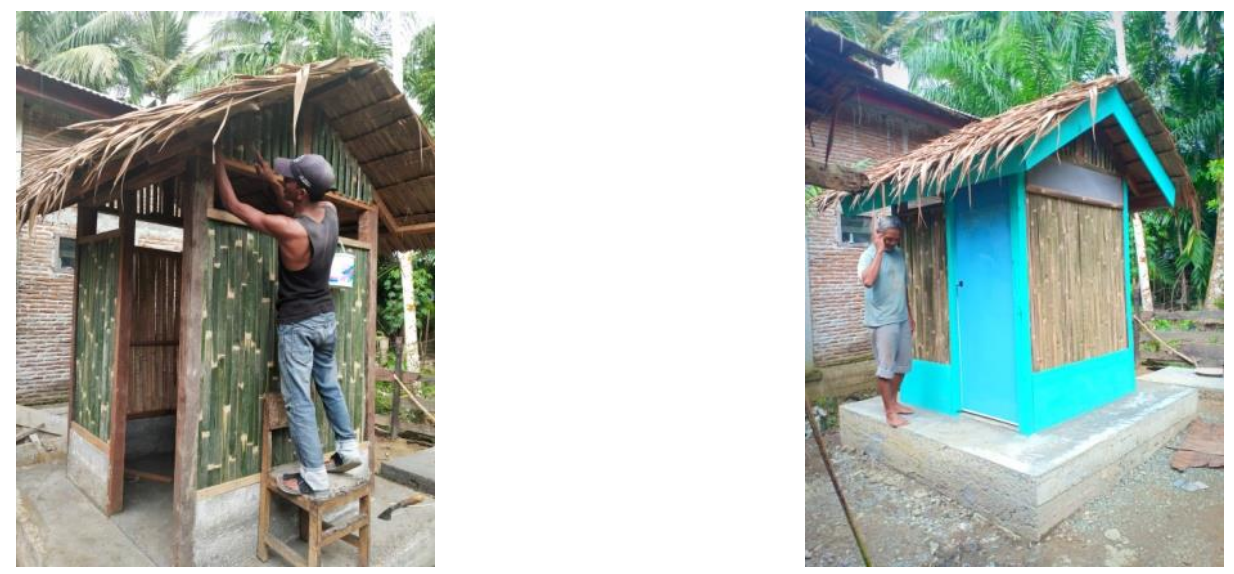

Gambar 11 Proses finishing jamban dan jamban telah selesai 


\section{KESIMPULAN DAN IMPLIKASI}

Kegiatan Pengabdian kepada Masyarakat (PKM) tentang pembuatan jamban ramah ingkungan bagi masyarakat yang berprofesi sebagai tukang bangunan di Desa Cotkuta Kecamatan Suka Makmue Kabupaten Nagan Raya telah dilaksanakan dengan lancar dan baik. Tim pengabdian bekerjasama dengan baik bersama tim mitra. Berbagai pihak terutama mitra dan aparatur desa berperan aktif dalam kegiatan pengabdian ini sehingga kegiatan telah berjalan sesuai yang diharapkan. Harapannya dapat memberikan manfaat bagi mitra pengabdian masyarakat dalam keberlanjutan untuk meningkatkan sanitasi lingkungan dengan membangun jamban ramah ingkungan ini.

Implikasi dari hasil pengabdian kepada masyarakat yang telah dilaksanakan adalah bertambah dan meningkatnya pemahaman dan keterampilan dari para mitra yaitu Kelompok Sejahtera. Hal ini ditunjukkan dari keaktifan dan anggota kelompok mitra yang antusias terlibat secara langsung dalam membuat jamban ramah ingkungan. Respon dari mitra sangat positif, dimana mitra mau menerima inovasi yang diberikan serta memiliki minat yang tinggi dan bersedia untuk menerapkan inovasi yang diberikan. Dengan adanya kegiatan lanjutan yang berupa pelatihan sejenis diselenggarakan secara periodik, dapat meningkatkan kemampuan anggota Kelompok Sejahtera sehingga anggota tim dapat menerapkan inovasi ini pada lingkungannya sendiri.

\section{ACKNOWLEDGMENT}

Ucapan terimakasih penulis sampaikan kepada LPPM-PMP Universitas UTU yang telah mendanai kegiatan ini dengan hibah internal Pengabdian Berbasis Riset (PBR). Terima kasih kepada mahasiswa yang telah terlibat dalam kegiatan PBR ini yaitu Maulana, Maisarah, Husnul dan Syifaul.

\section{DAFTAR PUSTAKA}

Badan Pusat Statistik. (2018). Kecamatan Suka Makmue Dalam Angka tahun 2018. BPS, Kabupaten Nagan Raya.

Departemen Kesehatan RI. (2009). Rumah Tangga An aerobdengan Perilaku Hidup Bersih dan Sehat, Depkes RI, Jakarta

Kusnoputranto, H., (2008). Kesehatan Lingkungan. FKM UI. Jakarta.

Madjid, (2009), Pengetahuan dan Tindakan Masyarakat Dalam Pemanfaatan WC Keluarga. Http://Datinkessulsel.Wordpress.com/2009/06/26/pengetahuan-dan-tindakan masyarakat dalam pemanfaatan WC keluarga/. Diakses 25 Juni 2019.

Notoatmodjo, S., (2010). Prinsip-prinsip dasar ilmu kesehatan masyarakat, Rineka Cipta, Jakarta.

Proverawati, A dan Rahmawati, E. (2012). PHBS (Perilaku Hidup Bersih dan Sehat). Nuha Medika, Yogyakarta. 